\title{
O ENSINO DO MAGISTÉRIO A RESPEITO DO SENSUS FIDEI
}

\author{
The Magisterial Teaching Concerning \\ THE SENSUS FIDEI
}

Catelan Ferreira*

\section{RESUMO}

O artigo faz uma análise do ensino do Magistério sobre o sensus fidei, tendo o Concílio Ecumênico Vaticano Il como centro. Por isso, inicia com o ensino antes dele; a seguir, expõe a doutrina exposta pelo Vaticano II na Lumen Gentium 12; prossegue estudando o tema nos documentos posteriores, a começar pelo Magistério pontifício, particularmente nos Papas João Paulo II, Bento XVI e Francisco, continuando com o Código de Direito Canônico, Catecismo da Igreja Católica e em documentos dos organismos da Cúria Romana. O autor conclui expondo algumas conclusões do percurso percorrido.

Palavras-chave: Sensus fidei. Vaticano II. Magistério. Cúria Romana.

\section{ABSTRACT}

This article analyzes the Magisterial teaching about sensus fidei, having the Ecumenical Vatican Council II as a center. Therefore, it begins with the teaching before it; Next, it exposes the doctrine exposed by Vatican II in Lumen Gentium 12 ; it continues studying the theme in the subsequent documents, starting by the papal Magisterium, particularly in the Popes John Paul II, Benedict XVI and Francisco, continuing with the Code of Canon Law, Catechism of the Catholic Church and in documents of the organisms of the Roman Curia. The author concludes exposing some conclusions of the path pursued.

Keywords: Sensus fidei. Vatican II. Magisterium. Roman Curia.

* Doutor em Teologia Dogmática pela Pont. Universidade Gregoriana de Roma; Professor no Programa de Pós-Graduação em Teologia da PUCPR; Membro da Comissão Teológica Internacional; Assessor da Comissão Episcopal Pastoral para a Doutrina da Fé, da CNBB. E-mail: <catelanferreira@uol.com.br>.

\begin{tabular}{|l|l|l|l|l|l|}
\hline Teocomunicação & Porto Alegre & v. 45 & n. 2 & p. 136-157 & maio-ago. 2015 \\
\hline
\end{tabular}




\section{Introdução}

O Concílio Vaticano II é um ponto de referência fundamental para a compreensão do que o Magistério eclesial ensina a respeito do sensus fidei. Mais, a exposição que faz da doutrina a este respeito encontra-se entre os aspectos de novidades de maior relevo desse Concílio. $L G 12$ é considerado, unanimemente, como a referência mais completa nesse âmbito. Do ponto de vista lexical, porém, os textos conciliares registram diversas ocorrências: sensus fidei: $L G$ 12, PO 9; sensus catholicus: AA 30; sensus christianus fidelium: GS 52; sensus christianus: GS 62; sensus religiosus: NA 2, DH 4, GS 59; sensus Dei: DV 15, GS 7; sensus Christi et Ecclesiae: $A G$ 19; instinctus: SC 24, PC 12, GS 18. Reconhece-se a importância de $D V 8$ - sobre a "intima spiritualium rerum quam experiuntur intelligentia - íntima inteligência que experimentam das coisas espirituais". ${ }^{1}$ Evidentemente, para além do exame lexical, seria de se distinguir cuidadosamente as ocorrências referentes ao sensus fidei como função de inteligência da fé operada por todo o povo de Deus das ocorrências que se referem a experiências, atitudes ou comportamentos inspirados na fé ou dela decorrentes.

Seu conteúdo, porém, não é novidade. É ensinamento bíblico e tradicional. O recente documento da Comissão Teológica Internacional (O sensus fidei na vida da Igreja - 2014) elenca uma série de textos bíblicos como fundamento da doutrina exposta ao longo de seus quatro capítulos. De modo especial, na primeira parte do capítulo primeiro (O sensus fidei na Escritura e na Tradição). A liturgia, os Padres, as expressões espontâneas do cristianismo ("monumentos da Tradição") ${ }^{2}$ testemunham a constância e a importância do sensus fidei para a vida da Igreja, especialmente para seu desenvolvimento dogmático.

Neste estudo, partindo do ensinamento conciliar, pretende-se examinar outras ocorrências do tema em documentos do Magistério do período pós-conciliar.

\footnotetext{
ALSZEGHY, Z., "El sentido de la fe y el desarollo dogmático", in: LATOURELLE, R. (org.), Vaticano II. Balance y perpesctivas veinte años después. Salamanca: Sígueme, 1989, p. 136; PIÉ-NINOT, S., "Sensus fidei”, in: LATOURELLE, R.; FISICHELLA, R. (orgs.), op. cit., p. 884.

2 CONGAR, Y. La tradition e les traditions, vol. 2: Essai théologique. Paris: Fayard, 1963, p. 183-213.
} 


\section{Precedentes magisteriais}

O modo como a doutrina é exposta no Concílio permite a conclusão de que não nos encontramos diante de uma doutrina nova. Mesmo que ela antes não tenha sido tratada reflexamente pelo Magistério, não se pode esquecer de que pouco mais de uma década antes do Concílio, Pio XII apoiara-se explicitamente sobre a mais importante manifestação do sensus fidei que é o consensus fidelium na declaração dogmática da Assunção de Maria ao céu. Efetivamente, consultou o episcopado católico por meio da encíclica "Deiparae Virginis Mariae" (01.05.1946), pedindo para ser informado a respeito da devoção do clero e do povo para com a assunção da Virgem Maria, e, ainda mais, se os bispos julgam "que a assunção corpórea da santíssima Virgem pode ser proposta e definida como dogma de fé, e se desejais que o seja, tanto vós como o vosso clero e fiéis". ${ }^{3}$ A apresentação do resultado de tal consulta, na Constituição Apostólica Munificentissimus Deus (01.11.1950) argumenta com elementos que são próprios dessa doutrina:

Aqueles que 'o Espírito Santo colocou como bispos para reger a Igreja de Deus' (At 20,28) quase unanimemente deram resposta afirmativa. Essa "singular concordância dos bispos e fiéis" (Pio IX, carta apostólica Ineffabilis Deus) em julgar que a assunção corpórea ao céu da Mãe de Deus podia ser definida como dogma de fé, mostra-nos a doutrina concorde do magistério ordinário da Igreja, e a fé igualmente concorde do povo cristão - que aquele magistério sustenta e dirige - e por isso mesmo manifesta, de modo certo e imune de erro, que tal privilégio é verdade revelada por Deus e contida no depósito divino que Jesus Cristo confiou a sua esposa para o guardar fielmente e infalivelmente o declarar (Cf. Conc. Vat. I, Const. dogm. Dei Filius de fide catholica, cap. 4). ${ }^{4}$

Igual procedimento e similar argumentação foram usados pelo papa Pio IX, um século antes, na declaração da Imaculada Conceição da Virgem Maria. A consulta foi feita com a encíclica Ubi primum nullis (02.02.1849), e a proclamação solene do dogma com a carta apostólica (bula) Ineffabilis Deus (08.12.1854), na qual utiliza termos como: "perpetuus Ecclesiae sensu - constante sentir da Igreja" e "singular

\footnotetext{
3 In: Enchiridion dele Encicliche, vol. 6, Bologna: EDB, 1995, p. 395.

${ }^{4}$ In: Acta Apostolicae Sedis 42 (1950), p. 756.
} 
consenso dos bispos católicos e dos fiéis - singularis catholicorum Antistitum ac fidelium conspiratio". ${ }^{5}$ Os especialistas fazem notar que Pio IX faz uso da linguagem empregada pelo teólogo Perrone (1847). O que torna este caso altamente significativo, pela confluência dos atos próprios do conjunto dos fiéis, dos teólogos e do Magistério.

Outros casos em que o Magistério se baseou para formular uma definição doutrinal são apresentados por Perrone ${ }^{6}$ e Newman. ${ }^{7}$ Os mais conhecidos são a doutrina cristológica sobre a natureza divina de Jesus Cristo e a doutrina de que os justos gozam da visão beatífica de Deus antes da ressurreição dos mortos.

\section{A doutrina exposta pelo Concílio Vaticano II}

Não sendo possível examinar todos os textos conciliares acima mencionados, a presente seção segue o texto fundamental, que é o número 12 da Constituição dogmática sobre a Igreja, e o examina recorrendo a alguns outros com temática paralela. $\mathrm{O}$ contexto desse parágrafo é muito significativo para sua interpretação. Encontra-se no capítulo II - O povo de Deus, no parágrafo que trata da participação de todos os fiéis na função profética de Cristo. "O Povo santo de Deus participa também da função profética de Cristo, difundindo o seu testemunho vivo, sobretudo pela vida de fé e de caridade, oferecendo a Deus o sacrifício de louvor, fruto dos lábios que confessam o Seu nome (cfr. $H b$ 13,15). ${ }^{8}$ Esse contexto está inserido em uma importante exposição da doutrina eclesiológica, na qual se destaca a infalibilidade da Igreja in credendo e o papel do consenso universal dos fiéis:

A totalidade dos fiéis que receberam a unção do Santo (cf. $J o$ $2,20.27$ ) não pode enganar-se na fé; e esta sua propriedade peculiar manifesta-se por meio do sentir sobrenatural da fé do povo todo, quando este, "desde os Bispos até ao último dos leigos fiéis" (Cf. S. Agostinho, De Praed. Sanct. 14, 27: PL 44, 980), manifesta consenso universal em matéria de fé e costumes. ${ }^{9}$

\footnotetext{
${ }_{5}$ PIO IX, Bula Ineffabilis Deus, Acta Pii IX, parte I, vol. 1, p. 615.

6 PERrone, G. De Immaculato B.V. Mariae Conceptu. An dogmatico decreto definiri possit, disquisitio theologica. Roma: Marini, 1847, p. 143-145.

7 NEWMAN, J. H. An essay on the development of Christian Doctrine. London: James Toovey, 1845.

${ }^{8} L G 12 \mathrm{a}$.

9 Ibid.
} 
A seguir, explicita a correlação entre o sensus fidei, Espírito Santo e Magistério eclesial: "com este sentido da fé, que se desperta e sustenta pela ação do Espírito de verdade, o povo de Deus, sob a direção do sagrado magistério que fielmente acata $[\ldots] " .{ }^{10} \mathrm{E}$, por fim, descreve o sensus fidei a partir de seus efeitos:

[O povo de Deus] já não recebe simples palavra de homens mas a verdadeira palavra de Deus (cf. 1 Tes 2,13), adere indefectivelmente à fé uma vez confiada aos santos (cf. $J d 3$ ), penetra-a mais profundamente com juízo acertado e aplica-a mais totalmente na vida. ${ }^{11}$

Comentando a passagem, F. A. Sullivan ${ }^{12}$ e S. Pié-Ninot ${ }^{13}$ chamam atenção para os verbos usados: o sentido da fé é suscitado e mantido pelo Espírito Santo (excitatur e sustentatur); é guiado pelo sagrado Magistério, que acata fielmente (sub ductu sacri magisterii, cui fideliter obsequens); o povo aceita (accipit) a palavra de Deus; adere a ela (adhaeret); penetra nessa palavra (penetrat) e a aplica à vida (applicat).

Pode ser útil retomar os elementos teológicos do sensus fidei apresentados por $L G 12$. Primeiramente, afirma-se que é um sentimento "sobrenatural" de caráter pneumatológico: é suscitado e sustentado pelo Espírito Santo. A este propósito recorde-se que da própria fé é feita idêntica afirmação por $D V 5$ ("para prestar a adesão da fé, são necessários a prévia e concomitante ajuda da graça divina e os interiores auxílios do Espírito Santo"), onde se descreve também o caráter carismático da compreensão da revelação ("para que a compreensão da revelação seja sempre mais profunda, o mesmo Espírito Santo aperfeiçoa sem cessar a fé mediante os seus dons").

Em segundo lugar, trata-se de uma "peculiaridade" de "todo" o povo de Deus. No contexto mencionam-se "a totalidade dos fiéis", "povo todo", "bispos e fiéis leigos". Portanto, não é algo setorial, ou de uma categoria de fiéis. Mais à frente, no capítulo quarto, sobre os fiéis leigos, na seção dedicada ao "testemunho de vida pelo apostolado dos leigos", a Constituição dá um ulterior esclarecimento ( $L G 35)$ :

\footnotetext{
${ }^{10} L G 12 \mathrm{a}$.

${ }^{11}$ Ibid.

12 Magisterium: Teaching Authority in the Catholic Church. Dublin-Mahwah, 1983, p. 21-23.

13 “Sensus fidei/sensus fidelium”, in: O’DONNELL, C.; PIÉ-NINOT, S. (orgs.), Diccionario de Eclesiologia, Madrid: San Pablo, 2001, p. 985-986.
} 
Cristo, o grande profeta, que pelo testemunho da vida e a força da palavra proclamou o reino do Pai, realiza a sua missão profética, até à total revelação da glória, não só por meio da Hierarquia, que em Seu nome e com a Sua autoridade ensina, mas também por meio dos leigos; para isso os constituiu testemunhas, e lhes concedeu o sentido da fé e o dom da palavra (cf. At 2,17-18; $A p$ 19,10) a fim de que a força do Evangelho resplandeça na vida quotidiana, familiar e social.

Finalmente, o texto descreve os efeitos deste dom. Como se trata de um senso DA FÉ, está correlacionado com a Palavra de Deus (como esclarece $D V$ 5). Com relação a ela, fala-se de recepção, adesão, penetração e aplicação. Neste mesmo sentido, $D V 8$, ao falar da transmissão da divina Revelação e do progresso da Tradição na vida da Igreja (cap. 2), reafirma o papel do Espírito Santo e do caráter "experiencial" e "espiritual (= sobrenatural)" do senso da fé.

Esta tradição apostólica progride na Igreja sob a assistência do Espírito Santo. Com efeito, progride a percepção tanto das coisas como das palavras transmitidas, quer mercê da contemplação e estudo dos crentes, que as meditam no seu coração (cf. Lc. 2,19.51), quer mercê da íntima inteligência que experimentam das coisas espirituais, quer mercê da pregação daqueles que, com a sucessão do episcopado, receberam o carisma da verdade. Isto é, a Igreja, no decurso dos séculos, tende continuamente para a plenitude da verdade divina, até que nela se realizem as palavras de Deus. ${ }^{14}$

Entre os quatro fatores mencionado por $D V$ 8, o sensus fidei está presente no terceiro e, parcialmente, no quarto. São eles: "a assistência do Espírito Santo", a "contemplação e o estudo dos crentes", a "compreensão interior das coisas espirituais" e o "anúncio daqueles que, com a sucessão do episcopado, receberam o carisma certo da verdade".

\section{O sensus fidei nos documentos do Magistério após o Concílio}

No exame do percurso feito pelo sensus fidei nos documentos magisteriais do pós-Concílio são examinados documentos e discursos pontifícios, o Código de Direito Canônico, o Catecismo da Igreja

\footnotetext{
${ }^{14} \mathrm{DV} 8 \mathrm{~b}$
} 
Católica e documentos de organismos da Cúria Romana e da Comissão Teológica Internacional. Não se trata, propriamente, de um estudo da recepção da doutrina conciliar, mas de um aspecto da recepção que é a utilização de um léxico específico e de conceitos que ele veicula.

\subsection{O Magistério pontifício}

Em dois documentos de grande envergadura, o Papa João Paulo II entrou na temática do sensus fidei. O primeiro deles é a exortação apostólica pós-sinodal Familiaris consortio (22.11.1981) onde discorre sobre as relações que pode haver entre o sensus fidei, o consensus fidelium e a opinião pública na Igreja e fora dela. Afirma que "o sensus fidei não consiste [...] somente ou necessariamente no consensus fidelium". E que cabe aos pastores da Igreja "promover o sentido da fé em todos os fiéis, vigiar e julgar com autoridade a genuinidade de suas expressões, e educar os crentes a um discernimento evangélico cada vez mais maduro". ${ }^{15}$

No segundo, a exortação apostólica pós-sinodal Christifideles laici (30.12.1988), menciona explicitamente que os leigos "são tornados participantes [...] do sentido de fé sobrenatural da Igreja - sensum fidei supernaturalis Ecclesiae" 16 quando trata da participação dos leigos no múnus profético de Cristo.

Causa um pouco de estranheza a ausência do tema em sua primeira encíclica, Redemptor hominis (04.03.1979), quando trata com certo pormenor da "Igreja responsável pela verdade". Aí ele afirma que "nos tornamos participantes da missão de Cristo profeta; e, em virtude da mesma missão e juntamente com Ele, servimos a verdade divina na Igreja. A responsabilidade por esta verdade implica também amá-la e procurar obter a sua mais exata compreensão, de maneira a torná-la mais próxima de nós mesmos e dos outros, com toda a sua força salvífica, com o seu esplendor e com a sua profundidade e simplicidade a um tempo". ${ }^{17}$ Foi no contexto da exposição dessa temática que a Dei Verbum (n. 8) deu uma importante contribuição ao aprofundamento da temática, mostrando a convergência do Magistério, da teologia e do sentido da fé de todo o povo de Deus. Esta encíclica, na sequência, explicita apenas o papel da teologia e do Magistério.

\footnotetext{
${ }^{15}$ FC 5, in: Enchiridion Vaticanum, v. 7, Bologna: EDB, 1982, p. 1397.1399.

${ }^{16}$ Cf, n. 14, in: Enchiridion Vaticanum, v. 11, Bologna: EDB, 1991, p. 1053.

${ }^{17}$ RH, n. 19, in: Enchiridion Vaticanum, v. 6, Bologna: EDB, 1980, p. 855.
} 
O Papa Bento XVI tratou do tema em um discurso à Comissão Teológica Internacional (7.12.2012). Embora não se trate de uma forma solene de exercício do Magistério pontifício, esse discurso merece aqui nossa atenção pelos importantes esclarecimentos que contém. Comentando a respeito do documento "Teologia hoje: perspectivas, princípios e critérios", publicado pela Comissão em 2011, ele afirma: "Entre os critérios da teologia católica, o documento menciona a atenção que os teólogos devem reservar ao sensus fidelium. É muito útil que a vossa Comissão se tenha concentrado também sobre este tema, que é de importância particular para a reflexão acerca da fé e para a vida da Igreja". ${ }^{18}$ A seguir, cita $L G 12$ e comenta:

Este dom, o sensus fidei, constitui no fiel uma espécie de instinto sobrenatural que tem uma conaturalidade vital com o próprio objeto da fé. Observemos que precisamente os simples fiéis trazem consigo esta certeza, esta segurança do sentido da fé. O sensus fidei é um critério para discernir se uma verdade pertence ou não ao depósito vivo da tradição apostólica. Apresenta também um valor propositivo, porque o Espírito Santo não cessa de falar às Igrejas e de as orientar para toda a verdade. ${ }^{19}$

E o distingue da "opinião pública eclesial":

Hoje, no entanto, é particularmente importante especificar os critérios que permitem distinguir entre o sensus fidelium autêntico e as suas imitações. Na realidade, ele não é uma espécie de opinião pública eclesial, e não é pensável que possa mencioná-lo para contestar os ensinamentos do Magistério, uma vez que o sensus fidei não pode desenvolver-se autenticamente no crente, a não ser na medida em que ele participa plenamente na vida da Igreja, e isto exige a adesão responsável ao seu Magistério, ao depósito da fé. ${ }^{20}$

Por fim, comentando a respeito de outro tema em estudo pela Comissão, "Deus-Trindade, unidade dos homens, Cristianismo e monoteísmo", indica um campo concreto em que a atenção ao sensus fidei pode oferecer uma contribuição de grande valor. Não obstante a extensão, parece justificado citar na íntegra a reflexão:

\footnotetext{
${ }^{18}$ In: $A A S 104$ (2014), p. 1040.

${ }^{19}$ Ibid.

${ }^{20}$ Ibid.
} 
Hoje, este mesmo sentido sobrenatural da fé dos crentes leva a reagir com vigor também contra o preconceito, segundo o qual as religiões, e de modo particular as religiões monoteístas, seriam intrinsecamente portadoras de violência, sobretudo por causa da pretensão que elas manifestam da existência de uma verdade universal. Alguns consideram que apenas o "politeísmo dos valores" garantiria a tolerância e a paz civil, e estaria em conformidade com o espírito de uma sociedade democrática pluralista. Neste sentido, os vossos estudos sobre o tema 'Deus-Trindade, unidade dos homens, Cristianismo e monoteísmo' é de profunda atualidade. Por um lado, é essencial recordar que a fé no Deus único, Criador do céu e da terra, encontra as exigências racionais da reflexão metafísica, que não é debilitada mas fortalecida e aprofundada pela Revelação do mistério do Deus-Trindade. Por outro, é necessário ressaltar a forma que a Revelação definitiva do Mistério do único Deus adquire na vida e na morte de Jesus Cristo, que vai ao encontro da Cruz como 'Cordeiro conduzido ao matadouro' (Is 53,7). O Senhor atesta uma rejeição radical de todas as formas de ódio e violência a favor do primado absoluto do agape. Por conseguinte, se na história houve ou há formas de violência perpetradas em nome de Deus, elas não devem ser atribuídas ao monoteísmo, mas a causas históricas, principalmente aos erros dos homens. Ao contrário, é precisamente o esquecimento de Deus que imerge as sociedades humanas numa forma de relativismo, que gera inevitavelmente a violência. Quando se nega a todos a possibilidade de se referirem a uma verdade objetiva, o diálogo torna-se impossível e a violência, declarada ou escondida, torna-se a regra dos relacionamentos humanos. Sem a abertura ao transcendente, que permite encontrar respostas às interrogações sobre o sentido da vida e a maneira de viver de modo moral, sem esta abertura o homem torna-se incapaz de agir em conformidade com a justiça e de se comprometer em prol da paz. ${ }^{21}$

O Papa Francisco trata desse tema no documento programático de seu pontificado, a exortação apostólica Evangelii gaudium, de modo explícito e implícito. A primeira menção ao sensus fidelium nesse documento é implícita. Encontra-se quando trata da renovação eclesial, que ele caracteriza como inadiável. O contexto é o do "sonho missionário de chegar a todos" e é a primeira vez que o sensus fidei é mencionado em perspectiva missionária. Ali, emprega a metáfora do "olfato":

${ }^{21}$ In: $A A S 104$ (2014), p. 1040-1041. 
O Bispo deve favorecer sempre a comunhão missionária na sua Igreja diocesana, seguindo o ideal das primeiras comunidades cristãs, em que os crentes tinham um só coração e uma só alma (cf. At 4,32). Para isso, às vezes pôr-se-á à frente para indicar a estrada e sustentar a esperança do povo, outras vezes manter-se-á simplesmente no meio de todos com a sua proximidade simples e misericordiosa e, em certas circunstâncias, deverá caminhar atrás do povo, para ajudar aqueles que se atrasaram e sobretudo porque o próprio rebanho possui o olfato para encontrar novas estradas. Na sua missão de promover uma comunhão dinâmica, aberta e missionária, deverá estimular e procurar o amadurecimento dos organismos de participação propostos pelo Código de Direito Canônico (cân. 460-468; 492-502; 511-514; 536537) e de outras formas de diálogo pastoral, com o desejo de ouvir a todos, e não apenas alguns sempre prontos a lisonjeá-lo. Mas o objetivo destes processos participativos não deve ser principalmente a organização eclesial, mas o sonho missionário de chegar a todos. ${ }^{22}$

Encontra-se uma exposição semelhante a esta no discurso aos dirigentes do CELAM (28.07.2013), onde também afirma: "O próprio rebanho tem o seu faro para encontrar novos caminhos" 23 (5.4). No presente texto é importante notar a alta articulação de temas: o estilo do exercício do ministério episcopal, a comunhão eclesial, os organismos eclesiais de participação, o paradigma missionário de toda atividade pastoral, etc. De modo que seu tratamento do sentido da fé não é de natureza conceitual.

Outra menção implícita pode ser encontrada no capítulo 2 ("Na crise do compromisso comunitário") quando trata dos desafios da inculturação. A piedade popular é descrita com características que fazem entrever o papel que nelas o sensus fidei desempenha.

O substrato cristão de alguns povos - sobretudo ocidentais - é uma realidade viva. Aqui encontramos, especialmente nos mais necessitados, uma reserva moral que guarda valores de autêntico humanismo cristão. Um olhar de fé sobre a realidade não pode deixar de reconhecer o que semeia o Espírito Santo. [...] Aqui há que reconhecer muito mais que "sementes do Verbo", visto que se trata de autêntica fé católica com modalidades próprias de expressão e de pertença à Igreja. [...] Uma cultura popular evangelizada contém

\footnotetext{
${ }^{22} E G$, n. 31, in: $A A S 105$ (2013), p. 1033.

${ }^{23}$ In: $A A S 105$ (2013), p. 704.
} 
valores de fé e solidariedade que podem provocar o desenvolvimento de uma sociedade mais justa e crente, e possui uma sabedoria peculiar que devemos saber reconhecer com olhar agradecido. ${ }^{24}$

No capítulo central da exortação, "o anúncio do Evangelho" (cap. 3), tratando da corresponsabilidade de todos os batizados na evangelização, ele vai explicitamente ao tema e o cita a partir da doutrina que se encontra em $L G 12$, à qual se refere sem citar textualmente. Infalibilidade in credendo e sensus fidei são apresentados como sinais do mistério do amor de Deus pela humanidade:

Em todos os batizados, desde o primeiro ao último, atua a força santificadora do Espírito que impele a evangelizar. O povo de Deus é santo em virtude desta unção, que o torna infalível in credendo, ou seja, ao crer, não pode enganar-se, ainda que não encontre palavras para explicar a sua fé. O Espírito guia-o na verdade e condu-lo à salvação (Cf. $L G$ 12). Como parte do seu mistério de amor pela humanidade, Deus dota a totalidade dos fiéis com um instinto da fé - o sensus fide - que os ajuda a discernir o que vem realmente de Deus. A presença do Espírito confere aos cristãos uma certa conaturalidade com as realidades divinas e uma sabedoria que lhes permite captá-las intuitivamente, embora não possuam os meios adequados para expressá-las com precisão. ${ }^{25}$

A última ocorrência explícita se verifica no contexto de sua exposição sobre a opção preferencial pelos pobres, que se encontra no capítulo 4, "a dimensão social da evangelização", na seção que trata da inclusão social dos pobres. Aí se vê uma abordagem de temas sociais carregados de densidade teológica e espiritual:

Para a Igreja, a opção pelos pobres é mais uma categoria teológica que cultural, sociológica, política ou filosófica. Deus "manifesta a sua misericórdia antes de mais" a eles (João Paulo II, Homilia em Santo Domingo, 11.12.1984). Esta preferência divina tem consequências na vida de fé de todos os cristãos, chamados a possuírem "os mesmos sentimentos que estão em Cristo Jesus" ( $F l$ 2, 5). Inspirada por tal preferência, a Igreja fez uma opção pelos pobres, entendida como uma 'forma especial de primado na prática

\footnotetext{
${ }^{24} E G$, n. 68, in: ibid., p. 1048-1049.

${ }^{25}$ Id., n. 119, in: ibid., p. 1069-1070.
} 
da caridade cristã, testemunhada por toda a Tradição da Igreja' (Solicitudo rei socialis, 30.12.1987, 42). Como ensinava Bento XVI, esta opção 'está implícita na fé cristológica naquele Deus que Se fez pobre por nós, para enriquecer-nos com sua pobreza' (Discurso Inaugural na Conferência de Aparecida, 13.05.2007, 3). Por isso, desejo uma Igreja pobre para os pobres. Estes têm muito para nos ensinar. Além de participar do sensus fidei, nas suas próprias dores conhecem Cristo sofredor. É necessário que todos nos deixemos evangelizar por eles. A nova evangelização é um convite a reconhecer a força salvífica das suas vidas, e a colocá-los no centro do caminho da Igreja. Somos chamados a descobrir Cristo neles: não só a emprestar-lhes a nossa voz nas suas causas, mas também a ser seus amigos, a escutá-los, a compreendê-los e a acolher a misteriosa sabedoria que Deus nos quer comunicar através deles. ${ }^{26}$

Na audiência geral de 15 de maio de 2013, em uma catequese sobre "a ação que o Espírito Santo realiza ao guiar a Igreja e cada um de nós para a Verdade", ele afirma que:

O Espírito Santo, como Jesus promete, orienta-nos 'para toda a verdade' $(J o 16,13)$; guia-nos não só para o encontro com Jesus, plenitude da Verdade, mas fá-lo inclusive "dentro" da Verdade, ou seja, faz-nos entrar numa comunhão cada vez mais profunda com o próprio Jesus, proporcionando-nos a compreensão das realidades de Deus. E não a podemos alcançar só com as nossas forças. Se Deus não nos iluminar interiormente, o nosso ser cristãos será superficial. A Tradição da Igreja afirma que o Espírito da verdade age no nosso coração, suscitando aquele 'sentido da fé' (sensus fidei) através do qual, como afirma o Concílio Vaticano II, o Povo de Deus, sob a guia do Magistério, adere indefectivelmente à fé transmitida, aprofunda-a com juízo reto e aplica-a mais plenamente na vida (cf. $L G 12)^{27}$

Um exame mais atento dos vários pronunciamentos do Papa Francisco sobre os leigos, sobre a comum dignidade dos cristãos, sobre a corresponsabilidade do povo de Deus pela missão, sobre as mulheres e

\footnotetext{
${ }^{26}$ Id., 198, in: ibid., p. 1103.

$27<$ http://w2.vatican.va/content/francesco/pt/audiences/2013/documents/papafrancesco 20130515_udienza-generale.html>.
} 
sobre o papel dos fiéis na sociedade podem revelar o quanto o tema do sensus fidei é assimilado profundamente em seu pensamento e o quanto ele perpassa o conjunto de seu ensinamento. Sobretudo, cabe lembrar aqui a amplitude da consulta que mandou fazer em preparação à Terceira Assembleia Extraordinária do Sínodo dos Bispos e à próxima Assembleia Geral Ordinária. Esse seu estilo revela o quanto considera vital o consensus fidelium.

\subsection{Documentos eclesiais gerais: Código de Direito Canônico e Catecismo da Igreja Católica}

O Código de Direito Canônico (1983) não contém referência explícita ao sensus fidei. Pode-se ver implícita a doutrina no cânon $750, \S 1$ :

Devem ser cridas como verdade divina e católica todas as verdades contidas na palavra de Deus escrita ou transmitida, que é o único depósito da fé confiado à Igreja, e que conjuntamente são propostas como divinamente reveladas seja pelo Magistério solene da Igreja, seja pelo seu Magistério ordinário e universal, que é verdadeiramente manifesto pela comum adesão dos fiéis sob a guia do sagrado Magistério. Em consequência, todos devem evitar qualquer doutrina contrária a este.

Aqui se encontra uma formulação que pode ser considerada restritiva, possivelmente pela dificuldade de expressar o conteúdo da doutrina da Lumen gentium em linguagem canônica. Aqui se encontra ligada ao sensus fidei uma compreensão da infalibilidade de tipo passivo, o que caracteriza o seu papel quase que como um eco fiel do magistério da Igreja. Tal hipótese se baseia no exame dos nove sucessivos projetos do Código de Direito Canônico desde o projeto conhecido como Lex Ecclesiae Fundamentalis, em cujo textos prior, o número 55 reportava o texto de $L G 12$ na íntegra (BOELENS). Em outros dois cânones, pode-se encontrar uma referência indireta. No cân. 208 se afirma que "entre todos os fiéis, por força de sua regeneração em Cristo, subsiste uma verdadeira igualdade na dignidade e no agir, e por tal igualdade todos cooperam na edificação do corpo de Cristo, segundo a condição e os deveres próprios de cada um. E o cân. 212, § 3: "de modo proporcional à ciência, à competência e ao prestígio de que gozam, os fiéis têm o direito, e às vezes até o dever de manifestar aos sagrados pastores o seu pensamento sobre o que se refere ao bem da Igreja; e de dá-lo a conhecer aos outros fiéis, restando salva a integridade da fé e dos costumes e o 
respeito para com os pastores, tendo presente ainda a utilidade comum e a dignidade das pessoas".

O Catecismo da Igreja Católica (1992) trata do sensus supernaturalis fidei no contexto da transmissão da Revelação, que foi confiado à Igreja em sua totalidade (n. 84). Os números 91 a 93 repetem literalmente o ensino conciliar. No número 99, o resumo é apresentado com termos mais livres: "Graças ao sentido sobrenatural da fé, o povo de Deus, no seu todo, não cessa de acolher o dom da Revelação divina, de nele penetrar mais profundamente e de viver dele mais plenamente".

Outras duas vezes o Catecismo retorna ao tema, ambas no artigo sobre a Igreja. Primeiro, afirmando que "o povo santo de Deus participa também da função profética de Cristo', sobretudo pelo sentido sobrenatural da fé, que é o de todo o povo, leigos e hierarquia, quando 'adere indefectivelmente à fé transmitida aos santos de uma vez por todas', aprofunda o conhecimento da mesma, e se torna testemunha de Cristo no meio deste mundo" (785).

Em seguida, tratando do Munus Docendi, afirma que "para manter a Igreja na pureza da fé transmitida pelos Apóstolos, Cristo, que é Verdade, quis fazer sua Igreja participante de sua infalibilidade. Mediante o sentido sobrenatural da fé, o povo de Deus adere indefectivelmente à fé, sob a guia do Magistério vivo da Igreja" (889). Ainda uma ocorrência no Início do Catecismo, aplicada ao tema específico que é o das revelações privadas, atribui ao sensus fidelium a capacidade de discernir e acolher o que "constitui um apelo autêntico de Cristo ou dos seus santos à Igreja".

\subsection{Documentos de organismos da Cúria Romana}

Dos organismos da Cúria Romana, encontramos cinco que se referem ao sensus fidei. O primeiro deles, a instrução pastoral Communio et progressio, sobre os meios de comunicação social publicada por mandato do Concílio Ecumênico II do Vaticano (23.05.1971), tratando da opinião pública e considerando que ela é "uma propriedade específica e uma nota distintiva da natureza social do homem", ${ }^{28}$ conclui que "as opiniões comuns e livres, pelo fato de refletir o pensamento e a vontade do povo, devem ser examinadas atentamente sobretudo pelas autoridades religiosas e civis". ${ }^{29}$ Ao tratar da opinião pública na Igreja, a instrução indica como fundamento o sentido da fé e da caridade:

\footnotetext{
${ }^{28}$ N. 25, in: $A A S 63$ (1971), p. 604.

${ }^{29}$ N. 32, in: ibid., p. 606.
} 
É necessário que os católicos se consciencializem daquela verdadeira liberdade de expressão de pensamento que o 'sensus fidei' e a caridade lhes conferem: o 'sensus fidei', que é estímulo e força do Espírito da Verdade, que os faz aderir, em união e sob a guia do Magistério, à Fé da Tradição-adesão profunda, e, por isso mesmo contínuo aprofundamento e aplicação na vida prática (GS 34); e a Caridade, que eleva aquela liberdade à comunhão na própria liberdade de Cristo, redentor que libertando-nos do pecado, nos tornou livres de tudo julgarmos segundo a sua vontade. As autoridades responsáveis favoreçam e procurem que exista na Igreja, graças à liberdade de expressão e de pensamento, uma troca legítima de opiniões. Estabeleçam, portanto, as normas e condições necessárias a este fim (GS 57). ${ }^{30}$

O documento, ao reafirmar a importância da liberdade de expressão em vista da formação da opinião pública na Igreja, considerando o pluralismo legítimo e o contexto histórico-cultural plural e com contínuas mudanças, chega a admitir a possibilidade de dissenso, enquadrado em precisas condições:

É muito vasto o campo em que o Diálogo, no interior da Igreja, se deve desenvolver. É certo que as verdades da fé pertencem à própria essência da Igreja, e não podem, de nenhum modo, ser deixadas à interpretação arbitrária dos indivíduos. Contudo, a Igreja está encarnada na história humana; deve adaptar-se às circunstâncias particulares de tempo e de lugar; deve procurar a melhor maneira de expor as verdades da fé às diferentes épocas e culturas e adaptar a sua ação às condições sempre mutáveis dos tempos. Em união leal com o magistério, cada um dos católicos pode e deve, portanto, comprometer-se, numa investigação livre, para melhor interpretar as verdades reveladas e melhor as poder apresentar aos diversos grupos em evolução. Este diálogo livre no seio da Igreja não prejudica a unidade, a solidariedade entre os fiéis; pelo contrário, favorece a concórdia e o encontro das diversas correntes de pensamento, através do confronto de pareceres dentro da opinião pública. Mas, para que este progresso se processe como convém, é necessário que reine a caridade, mesmo nos casos de diferença de pontos de vista e opiniões. Neste diálogo, todos devem procurar e desejar servir e consolidar a união e cooperação, animados pela vontade de construir e não de destruir. Movidos por um profundo amor à Igreja e zelo de unidade, lembrar-se-ão que Cristo fez da unidade o sinal distintivo da verdadeira Igreja e dos verdadeiros discípulos. ${ }^{31}$

\footnotetext{
${ }^{30}$ N. 116, in: ibid., p. 634-635.

${ }^{31}$ N. 117, in: ibid., p. 635.
} 
A Congregação para a Doutrina da Fé publicou dois documentos em que o tema é considerado. O primeiro é a declaração Mysterium Ecclesiae (24.06.1973). O texto intervém em um contexto de questionamentos ao Magistério: as polêmicas em torno da Humanae vitae e a contestação radical de Hans Küng ("retomar e explicar algumas verdades sobre o mistério da Igreja que hoje são negadas ou postas em perigo"). ${ }^{32}$ Todo o número dois é dedicado à infalibilidade da Igreja. A argumentação toma partida da Dei Verbum: "Deus, na sua bondade infinita, dispôs que permanecesse para sempre na sua integridade a Revelação por ele feita, para a salvação de todos os povos". ${ }^{33}$ Para tanto, confiou ele esse tesouro da Palavra de Deus à Igreja; assim, os Pastores e o Povo santo, conjuntamente, concorrem para a sua conservação, aprofundamento e aplicação à vida. ${ }^{34}$ Para isto, continua o texto:

O próprio Deus, portanto, o qual é o absolutamente infalível, quis dotar o seu Povo novo, que é a Igreja, da prerrogativa de uma certa infalibilidade participada, que se circunscreve aos limites daquilo que diz respeito à fé e aos costumes e se verifica de fato quando todo o Povo de Deus sustenta sem incertezas qualquer ponto doutrinal, atinente a essa mesma matéria de fé e de costumes. Tal infalibilidade, porém - não se esqueça - está em permanente dependência do Espírito Santo, o qual, com providente sapiência e com a unção da sua graça, guia a Igreja para a verdade plena, até à vinda gloriosa do seu Senhor. ${ }^{35}$

Essa prerrogativa de todo o povo de Deus é vinculada à comunhão hierárquica, e o sensus fidei precisa ser correlacionado ao ofício próprio do Magistério:

Os fiéis, participantes também eles, em certa medida, na missão profética de Cristo, contribuem, sem dúvida, de diversas maneiras, para aumentar a compreensão da fé na Igreja (cita $D V$ 8) [...]. Por instituição divina, no entanto, ensinar os fiéis autenticamente, quer dizer, com a autoridade de Cristo, participada de diversas maneiras, é da competência exclusiva dos Pastores. ${ }^{36}$

\footnotetext{
32 Introdução, in: AAS 65 (1973), p. 396.

${ }^{33} \mathrm{DV} 7$.

${ }^{34}$ Id., n. 10.

${ }^{35}$ N. 2, in: $\operatorname{AAS} 65$ (1973), p. 398.

${ }^{36}$ Id., in: ibid., p. 399.
} 
O segundo documento da Congregação para a Doutrina da Fé é a instrução Donum veritatis sobre a vocação eclesial do teólogo (24.05.1990). Esta instrução se coloca no final de um período de ásperas discussões sobre a herança do Concílio Vaticano II e sobre quem tem direito de palavra na Igreja (H. Küng - J. Moltmann, 1981; E. Schillebeeckx, 1985). Aqui o tema do sensus fidei é tratado em correlação com a questão do dissenso:

Às vezes a dissensão recorre também a uma argumentação sociológica, segundo a qual a opinião de um grande número de cristãos seria uma expressão direta e adequada do "senso sobrenatural da fé". Na realidade as opiniões dos fiéis não podem ser pura e simplesmente identificadas com o sensus fidei (Familiaris consortio, 5). Este é uma propriedade da fé teologal, a qual, sendo um dom de Deus, que faz aderir pessoalmente à Verdade, não pode enganar-se. Esta fé pessoal é também fé da Igreja, porque Deus confiou à Igreja a guarda da Palavra, e, consequentemente, o que deve crer o fiel é aquilo que a Igreja crê. O sensus fidei implica, portanto, por sua natureza, a conformação profunda do espírito e do coração com a Igreja, o sentire cum Ecclesia. ${ }^{37}$

Chamando em questão os possíveis erros nas opiniões dos fiéis, muitos dos quais veiculados pelos meios de comunicação social, o documento argumenta mostrando a necessidade da correlação entre o sensus fidei e o Magistério eclesial:

Se, portanto, a fé teologal enquanto tal não se pode enganar, o fiel pode, ao contrário, ter opiniões errôneas, porque nem todos os seus pensamentos procedem da fé. Nem todas as ideias que circulam entre o Povo de Deus são coerentes com a fé, tanto mais que podem facilmente sofrer a influência de uma opinião pública veiculada pelos modernos meios de comunicação. Não é sem motivo que o Concílio Vaticano II sublinha a relação indissolúvel entre o sensus fidei e a orientação do Povo de Deus por parte do magistério dos Pastores; as duas realidades não podem ser separadas uma da outra ( $L G$ 12). As intervenções do Magistério servem para garantir a unidade da Igreja na verdade do Senhor. Ajudam a "permanecer na verdade", frente ao caráter arbitrário das opiniões mutáveis, e são a expressão da obediência à Palavra de Deus ( $D V 10)$. Mesmo

\footnotetext{
${ }^{37}$ N. 35, in: $A A S 82$ (1990) 1565-1566.
} 
quando pode parecer que limitem a liberdade dos teólogos, elas instauram, por meio da fidelidade à fé que foi transmitida, uma liberdade mais profunda, que não pode provir senão da unidade na verdade (Ibid.).

A Comissão Teológica Internacional, em dois de seus documentos recentes, aborda o tema. O Primeiro é "Teologia hoje: perspectivas, princípios e critérios" (2012). O segundo capítulo desse documento trata dos loci da teologia e de seu peso relativo. Logo após a Escritura e a Tradição, consta a "atenção ao sensus fidelium". Depois de retomar sinteticamente a doutrina referente ao tema na Lumen gentium e na Dei Verbum, o documento oferece uma descrição do sensus fidei:

A natureza e a localização do sensus fidei ou sensus fidelium deve ser devidamente compreendidas. O sensus fidelium não significa simplesmente a opinião da maioria em um determinado tempo ou cultura, nem é apenas uma afirmação secundária em relação com o que vem primeiro ensinado pelo Magistério. O sensus fidelium é o sensus fidei do povo de Deus na sua totalidade, obediente à Palavra de Deus e guiado nos caminhos da fé por seus pastores. Assim, o sensus fidelium é o sentido da fé que está profundamente enraizada no povo de Deus, que recebe, compreende e vive a Palavra de Deus na Igreja. ${ }^{38}$

Em seguida, explicita a importância da atenção ao sensus fidei por parte dos teólogos:

Para os teólogos, o sensus fidelium é de grande importância. Não é apenas um objeto de atenção e de respeito, é também base e locus para o seu trabalho. Por um lado, os teólogos dependem do sensus fidelium, pois a fé que eles exploram e explicam vive no povo de Deus. É claro, portanto, que os teólogos mesmos devem participar da vida da Igreja para terem verdadeira consciência dela. Por outro lado, parte do serviço especial dos teólogos dentro do corpo de Cristo é justamente o de explicar a fé da Igreja assim como é encontrada nas Escrituras, na liturgia, nos credos, nos dogmas, nos catecismos e no próprio sensus fidelium..$^{39}$

\footnotetext{
${ }^{38}$ N. 33, in: <http://www.vatican.va/roman_curia/congregations/cfaith/cti_documents/rc cti doc 20111129 teologiaoggi po.html>.

${ }^{39}$ N. $\overline{3} 4$, in: ibid.
} 
E conclui: "Atenção ao sensus fidelium é um critério para a teologia católica". ${ }^{40}$

O segundo documento recente da Comissão que trata do sensus fidei, o tem por objeto principal de seu estudo e trata dos vários aspectos. Por isso nos remetemos ao artigo de G. B. Hackman, neste número, que faz uma apresentação global do mesmo.

\section{Conclusão}

Seguir a recepção do ensinamento conciliar não se circunscreve, como fazemos no presente estudo, a verificar as diversas ocorrências da expressão. Exigiria um pouco mais, uma vez que a novidade não se encontra tanto em seu conteúdo. Este, de fato, expressa uma doutrina amplamente atestada pela tradição teológica. O novo que o Concílio introduziu está principalmente no enquadramento eclesiológico. Situando a exposição da doutrina sobre o sensus fidei no contexto da igualdade fundamental dos membros do povo de Deus quanto à dignidade e a comunhão de todos na mesma missão, o Concílio faz mais que repetir uma doutrina estabelecida. $L G 12.35$ e $D V 8$ lidos em conjunto e, sobretudo o papel atribuído ao sensus fidei no progresso da Tradição, sem relativizar o que compete ao Magistério, destaca junto a ele o papel do sensus fidelium e da teologia nesse progresso (VITALI, 1993, p. 259-266).

A efetiva recepção de um tal ensinamento consiste em bem mais que expor a doutrina e aprofundar seus elementos. Exige um processo de participação, escuta e consulta efetivos. Tal processo é que precisa ser examinado. E precisa-se examinar também em que medida o sensus fidei e seu corolário que é o consensus fidelium são efetivamente presentes na teologia e nos pronunciamentos do Magistério. É verdade que é preciso considerar com precisão o lugar do sensus fidei, como faz a Comissão Teológica Internacional em seu documento sobre a Teologia hoje. E é preciso igualmente ter em conta que o Magistério não precisa o consentimento do conjunto dos fiéis para exercer sua ministério. Porém, não é este, porém, o objetivo deste ensaio. Ele se circunscreve à tarefa mais modesta de examinar o percurso da expressão.

Algumas conclusões que podem ser tiradas desse rápido percurso, expostas em forma de teses:

${ }^{40}$ N. 36, in: ibid. 
1 - O contexto pós-conciliar, com turbulências extra e intra eclesiais, não favoreceu uma assimilação serena da doutrina conciliar sobre o sensus fidei. Alguns elementos foram acentuados, como a liberdade do Magistério, e outros ficaram na sombra, como o tema do consenso e da consulta.

2 - É preciso ter clareza sobre os termos envolvidos, sua conexão recíproca e sua distinção: infalibilidade eclesial in credendo, sensus fidei, sensus fidelium, consensus fidelium e sentire cum Ecclesia. O campo semântico é o mesmo, mas cada expressão tem seu significado preciso.

3 - O tema da opinião pública na Igreja é correlato e, ao mesmo tempo, por diversas razões, se distingue do sensus fidei.

4 - A efetiva participação na vida da Igreja e o exercício da corresponsabilidade na missão, são condições para que o sensus fidei se desenvolva e manifeste sua riqueza e profundidade.

5 - A necessidade de contínua formação e de atenção aos sinais dos tempos é uma exigência para que o sensus fidei se mantenha em sua genuinidade e seja relevante para a vida e a missão eclesial.

6 - O aprofundamento e a aplicação prática dessa doutrina vai junto com a recepção da eclesiologia conciliar. Nela se destacam a sacramentalidade da Igreja, sua natureza comunional e sua condição de povo de Deus peregrino.

7 - A piedade popular é um exemplo característico do sensus fidei inculturado, mesmo que também ela precise continuamente ser evangelizada.

8 - A efetiva participação de todo o povo de Deus nos processos de reflexão sobre os desafios à evangelização e nas tomadas de decisão, de acordo com os carismas e ministérios, é uma exigência do sensus fidei.

9 - O potencial evangelizador e missionário do sensus fidei é um elemento que indica um fecundo caminho de recepção do Concílio.

10 - O compromisso eclesial sóciotransformador é um campo em que o sensus fidei manifesta sua potencialidade.

\section{Referências}

ALSZEGHY, Z. El sentido de la fe y el desarollo dogmático. In: LATOURELLE, R. (Org.). Vaticano II. Balance y perpesctivas veinte años después. Salamanca: Sígueme, 1989. p. 105-116. 
BOELENS, O. G. M. Synopsis “Lex Ecclesiae Fundamentalis”. Leuven: Peters, 2001. Catecismus Catholicae Ecclesiae. (Roma, 1997). Trad. brasileira: Catecismo da Igreja Católica. São Paulo; Petrópolis, 1992.

Codex Iuris Canonici, auctoritate Iohannis Pauli PP. II promulgatus, AAS 75/II (1983) 1-301. Trad. brasileira: Código de Direito Canônico. São Paulo: J. Hortal, Ed., 1983.

CONCÍLIO ECUMÊNICO VATICANO II, Constitutio dogmatica de Ecclesiae Lumen Gentium (21.11.1964), AAS 57 (1965) 5-71.

. Constitutio dogmatica de divina Revelatione Dei Verbum (18.11.1965). AAS 58 (1966) 817-830.

. Constitutio pastoralis de Ecclesia in mundo huis temporis Gaudium et Spes (07.12.1965). AAS 58 (1966) 1025-1115.

CONGAR, Y. La Tradition e les traditions. Paris: Fayard, 1963. Vol. 2: Essai théologique.

CONGREGAÇÃO PARA A DOUTRINA DA FÉ, “Instructio de Ecclesiali Theologi vocatione [Donum veritatis]" (24.05.1990). AAS 82 (1990) 1550-1570.

CONSELHO PONTIFÍCIO PARA AS COMUNICAÇÕES SOCIAIS. Instrução pastoral "Communio et progressio, sobre os meios de comunicação social publicada por mandato do Concílio Ecumênico II do Vaticano”. In: AAS 63 (1971) 593-656.

JOÃO PAULO II. Adh. ap. Familiaris consortio. In: AAS 74 (1982) 181-191.

. Adh. ap. post-synodalis Christifideles laici, de vocatione et missione laicorum in Ecclesia et in mundo. In: AAS 81 (1989) 393-521.

KÜNG, H.; MOLTMANN, J. Quem tem a palavra na Igreja - número monográfico. Concilium 17 (1981/8) 11-124.

NEWMAN, J. H. An essay on the development of Christian Doctrine. London: James Toovey, 1845.

PERRONE, G. De Immaculato B.V. Mariae Conceptu. An dogmatico decreto definiri possit, disquisitio theologica. Roma: Marini, 1847.

PIÉ-NINOT, S. Sensus fidei. In: LATOURELlE, R.; FISICHELlA, R. (Orgs.). Dicionário de Teologia Fundamental. Petrópolis: Vozes; Aparecida: Santuário, 1990. p. 884-886.

. Sensus fidei/sensus fidelium. In: O’DONNELL, C.; PIÉ-NINOT, S. (Orgs.). Diccionario de Eclesiologia. Madrid: San Pablo, 2001. p. 984-987.

PIO IX. Carta encíclica Ubi primum nullis. In: Pii IX Pontificis Maximi Acta: I/1, Roma: Ed. Pol. Vat. p. 162-166.

. Carta apostólica (bula) Ineffabilis Deus. In: Pii IX Pontificis Maximi Acta: I/1, Roma: Ed. Pol. Vat. p. 597-619.

PIO XII, Constituição apostólica Munificentissimus Deus. In: AAS 42 (1950) 753-771. 
SCHILLEBEECKX, E. Magistério de todos: reflexão sobre a estrutura do Novo Testamento. In: Concilium (1985). p. 16-26.

SULIVAN, F. A. Magisterium: Teaching authority in the Catholic Church. DublinMahwah, 1983.

VITALI, D. Sensus fidelium. Una funzione di intelligenza della fede. Brescia: Morcelliana, 1993.

Recebido: $14 / 04 / 2015$

Avaliado: 27/04/2015 